\title{
PESTICIDE POISONING OF HONEYBEES: A REVIEW OF SYMPTOMS, INCIDENT CLASSIFICATION, AND CAUSES OF POISONING
}

\author{
Tomasz Kiljanek* \\ Alicja Niewiadowska \\ Andrzej Posyniak \\ National Veterinary Research Institute, Puławy, Poland \\ *corresponding author: tomasz.kiljanek@piwet.pulawy.pl \\ Received: 18 April 2016; accepted: 19 August 2016
}

\section{Abstract}

During the 2000s, the problem of pesticide poisoning of honeybees seemed to be almost solved. The number of cases has decreased in comparison to the 1970s. The problem of acute honeybee poisoning, however, has not disappeared, but instead has transformed into a problem of poisoning from 'traditional' pesticides like organophosphorus pesticides or pyrethroids, to poisoning from additional sources of 'modern' systemic neonicotinoids and fipronil. In this article, the biological activity of pesticides was reviewed. The poisoning symptoms, incident definitions, and monitoring systems, as well as the interpretation of the analytical results, were also reviewed. The range of pesticides, and the detected concentrations of pesticides in poisoned honeybee samples, were reviewed. And, for the first time, cases of poisoning related to neonicotinoids were reviewed. The latter especially is of practical importance and could be helpful to analysts and investigators of honeybee poisoning incidents. It is assumed that secondary poisoning induced by plant collected materials contaminated with systemic pesticides occurs. Food stored in a hive and contaminated with systemic pesticides consumed continuously by the same generation of winter bees, may result in sub-lethal intoxication. This leads to abnormal behaviour identified during acute intoxication. The final result is that the bees discontinue their social role in the honeybee colony super organism, and colony collapse disorder (CCD) takes place. The process described above refers primarily to robust and strong colonies that were able to collect plenty of food due to effective plant protection.

Keywords: colony collapse disorder, fipronil, honeybee poisoning, neonicotinoids, secondary poisoning, systemic pesticides

\section{INTRODUCTION}

In recent years, there has been a global decline in the honeybee population. In many European and North American countries, beekeepers and scientist reported huge losses of honeybee colonies. The latest data from the United States showed the unexpected finding that commercial beekeepers were reporting greater total summer loss than total winter loss (Seitz et al., 2015). When the honeybee colonies take the opportunity to use the plant flowering season to reinforce themselves after the hard winter period, they may be exposed to potentially toxic pesticides by several routes summarised on Fig. 1.

Honeybees are exposed to different types of natural and artificial chemical substances. Pesticides аге the second group of man-made chemicals in the world after the fertilisers, as concerns the amount applied and the extent of use (AAAS, 2013). Within the European Union there are 484 active substances approved for use as pesticides and 793 substances no longer approved for use as pesticides according to Regulation (EC) No 1107/2009.

Overwintered, old, and poorly fed bees are more vulnerable to pesticides than young ones. This is most likely true because such bees have a decrease of vitellogenin - a hemolymph protein with antioxidant properties (Johnson, 2015). Compared to other insects, honeybees are extremely sensitive to pesticides, due to a deficiency in the number of genes encoding detoxification enzymes (Atkins, 1992; Claudianos et al., 2006). Intraspecific genetic differences also have an impact on the susceptibility 


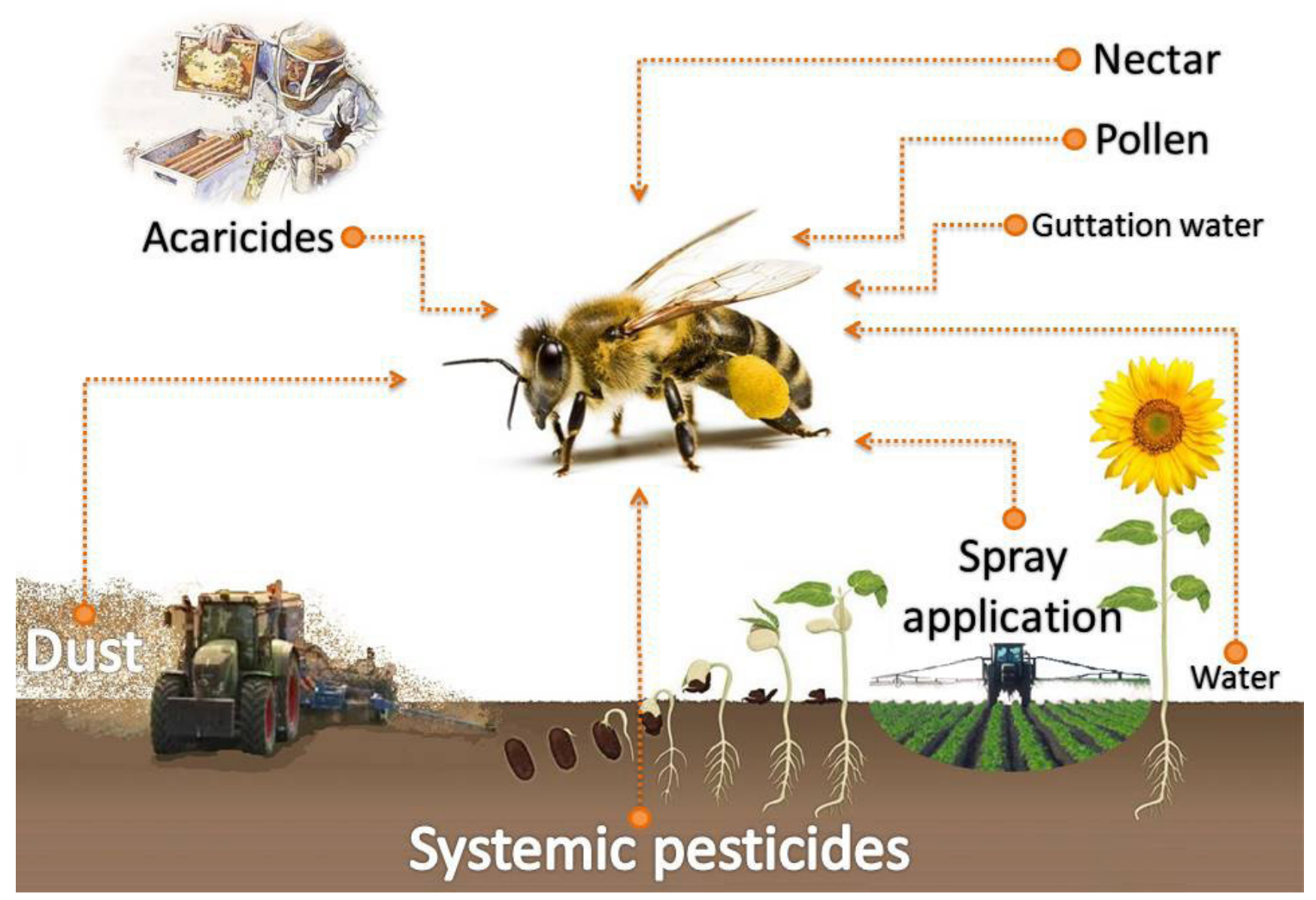

Fig. 1

Different routes by which honeybees may be exposed to pesticides.

to pesticides, e.g. imidacloprid (Suchail, Guez \& Belzunec, 2001).

To minimise the risk of honeybee poisonings or unacceptable weakening of a colony, the registration procedures of plant protection products (PPPs) take this issue into account. Many authors note the overall decline in bee pesticide poisoning incidents in most countries of Europe and North America as a consequence of proper and sufficient risk management. The number of incidents investigated in the United Kingdom and the number of incidents attributed to pesticides has halved during each 5 year period from 1994 to 2003 (Barnett, Charlton \& Fletcher, 2007). In Germany, the number of samples with damaged bees sent for the investigation, also decreased from more than 400 in the 1970s to 67 in 2004 (vanEngelsdorp \& Meixner, 2010). The above mentioned figures may seem to assure that currently approved pesticides do not pose an unacceptable risk to honeybees. This is a simplified and far-reaching conclusion. The latest data from Germany indicates a significantly increased number of samples that have been sent and chemically analysed as part of the investigation into honeybee poisoning incidents (Bischoff et al., 2010). Analytical methods used during the investigation of poisoning incidents may have inadequate scope or limits of detection of analysed pesticides. Also monitoring systems worked out on the basis of only contact honeybee poisonings could become obsolete in respect to the risks related to systemic insecticides.

Post-registration monitoring of honeybee poisonings provides real data of what pesticides have poisoned bees, and what residue concentrations detected in dead bee samples indicate the poisoning. Concentrations of pesticides in honeybees are the best measure of honeybee 
exposure, and the best measure of the bioavailability of pesticides after PPPs application. Bee-collected plant materials are not as great a measure (Blacquiére et al., 2012). Such systems and schemes should allow collecting real data in a standardize way in order to compare the scale of poisoning and corresponding residues in dead honeybees, as well as to compare plant products collected and stored in the affected hives. From gathered data it is known that not all colonies get weaker to the same extent. The extent of colonies damaged in confirmed honeybee poisoning incidents varied between 10-90\% (Pistorius et al., 2009). These figures mean that without honeybee poisoning monitoring data, it would be almost impossible to obtain one common result from controlled experimental data, since there are too many variables. The already published field trials which concluded that there were no effects on honey bees from neonicotinoids, were statistically incapable of detecting predicted sublethal effects (Cresswell, 2011). From a compilation of retrospective data, it is known that contaminated food stores caused increased prolonged mortality (Pistorius et al., 2009) of up to several weeks. This data was experimentally confirmed with dietary exposure to contaminated pollen (Pistorius et al., 2015). Beebread may be a reservoir of toxic systemic pesticides which when constantly eaten by wintering bees, leads to secondary sub-poisoning. Even similar and less intensive symptoms of acute poisoning (during the time when the poisoned bees could not be replaced), would lead to the perdition of honeybee social roles and to the rest of the honeybees removing themselves from their colony (Rueppell, Hayworth \& Ross, 2010). There are indications that reduced pollinationservice delivery is not due to pesticide-induced changes in individual bee behaviour, but most likely due to effects at the colony level (Stanley et al., 2015). This information is valuable for scientists, regulators, agrochemical companies, farmers, beekeepers, and enforcement authorities. These data could help improve risk assessment processes used during registration of PPPs. The data could also help to establish accurate guidance for inspection and controlling the risk of already approved pesticide uses, by standardisation of monitored systems.

\section{Biological activity of pesticides in honeybees}

It is necessary to include data about the modes of action of the insecticides, even if limited only to groups of substances determined as being the main cause of honeybee poisoning. The sublethal effects of insecticides on cognitive, behavioural, and physiological functions of honeybees have already been studied (Desneux, Decourtye \& Delpuech, 2007; Belzunces, Tchamitichian \& Brunet, 2012).

Neonicotinoids act on different subtypes of the nicotinic acetylcholine receptors (nAChRs) which are located entirely in the central nervous system of insects. Neonicotinoids initially increase the frequency of spontaneous discharge but will further completely block nerve propagation (Ensley, 2012). These compounds imitate the natural neurotransmitter acetylcholine, and mainly act agonistically on post synaptic nAChRs (Van der Sluijs et al., 2013). Death of the insect occurs as a result of neuronal hyper-excitation. Nitro substituted neonicotinoids, such as imidacloprid, clothianidin, and thiamethoxam, are more toxic to bees than cyano substituted ones. Some of neonicotinoid metabolites are also neurotoxin and are involved in honeybee mortality.

Phenylpyrazole fipronil block gamma-aminobutyric acid (GABA) receptors and furthermore block glutamate-activated chloride channels (GluCls). The central nervous system of insects is thus disrupted (Narahashi et al., 2010). Fipronil, like organophosphorus insecticides, causes hyperexcitation of the nerves and muscles of insects. At sufficient concentrations, Fipronil causes paralysis and death. Studies on several crops showed Fipronil metabolism in plants to fipronil-amide, fipronil-sulfone, and fipronilsulfide, whilst after foliar application, additional photodegradation to desulfinyl-fipronil occurs (Simon-Delso et al., 2015).

Organophosphorus insecticides inhibit acetylcholinesterase (AChE), the enzyme that catalyzes the hydrolysis of neurotransmitter acetylcholine. Acetyl cholinesterase chemically 
reacts with an insecticide and as a consequence AChE cannot fulfil its function resulting in gradual accumulation of neurotransmitter at the nerve synapse or neuro-muscular junction, and continuous stimulation of nerve fiber or muscle. Organophosphorus insecticides containing $\mathrm{P}=\mathrm{S}$ are less reactive than those having $\mathrm{P}=0$ in their structure. Chlorpyrifos containing $\mathrm{P}=\mathrm{S}$ group during a metabolic oxidation reaction, as part of the animal's defence system, forms a much more toxic $\mathrm{P}=0$ structure. Organophosphorus insecticides could lead to general perturbation in all systems (Desneux, Decourtye \& Delpuech, 2007).

Pyrethroids are able to alter the sodium channel function of cells in insect neuronal membranes, thereby disrupting electrical signalling in the nervous system (Soderlund, 2010). But there is broad agreement that pyrethroids affect a variety of voltage- and ligand-gated ion channels such as chloride and calcium ones. The inhibition of cells (but without a lethal effect), causes a knockdown phenomenon in insects. A variety of ion channels affected by different pyrethroids suggests that it is not appropriate to assess the risks of cumulative exposure to multiple pyrethroids with simple additivity models (Soderlund et al., 2002).

As far as the mode of action of individual groups of pesticides is concerned, a new challenge is to understand the toxicity of pesticide mixtures. It needs to be highlighted, that risk assessment during the registration process is done individually for each compound, while synergy effects between pesticides from different groups of uses occurs and are utilised by PPPs producers. In order to overcome the inadequate efficacy or considerably lower permitted application rates of active compounds, the synergistic effects of insecticides and fungicides are exploited. In such cases, the activity of the mixture is greater than the activity of the individual components. Novel active compound combinations consisting of at least one neonicotinoid (clothianidin, thiacloprid, dinotefuran, acetamiprid, nitenpyram, imidacloprid or thiamethoxam) and benalaxyl $M$ and/or metalaxyl $M$, are synergistically effective and have surprisingly good insecti- cidal and fungicidal properties (Krohn, Becker \& Hungenberg, 2008). Even the combination of four pesticides comprising fipronil or ethiprole and three fungicides are patented (Voeste, Haden \& Oloumi-Sadeghi, 2014). That is why more attention should be paid to specific residue mixtures because they may result in synergistic toxicity to bees (Sanchez-Bayo \& Goka, 2014).

\section{Symptoms of honeybee poisoning-definition of incident}

The fundamental symptom indicating that poisoning occurs is the high number of dead bees. The figures established by the FAO as guidelines for assessing the extent of pesticide poisoning are: that 100 dead bees per day is the colony's normal death rate; $200-400$ dead bees indicate a low level of pesticide poisoning; 500-1000 dead bees indicate a medium level of pesticide poisoning; over 1000 dead bees indicate a high level of pesticide poisoning (Akratanakul, 1990). Information has been gathered by the EFSA about natural background mortality. The information incorporates a value of $5.3 \%$ daily forager mortality as a conservative acceptable level for risk assessment on bees (EFSA, 2013). The critical mortality threshold of 250 dead bees per station per week found in the underbasket trap, was used by researchers for proving potential bee poisoning risks (Porrini et al., 2003). However, this figure is not the actual mortality rate because only a small portion of the total of dead bees can be found in the trap. In Germany and Poland, the investigation of honeybee poisoning occurs when at least 1000 dead bees are collected (JKI, 2010; PIWET, 2016). The Canadian Pest Management Regulatory Agency (PMRA) classifies bee poisoning incidents as 'minor', 'moderate', or 'major'. The classification is based not only on the number of dead bees but also on the abnormal behavioural effects exhibited by $\leq 10 \%$ of bees in any one colony, $10-30 \%$ of bees in any one colony (1000-3000 bees from each of five or more colonies), or at least $30 \%$ of bees in any one colony (at least 3000 bees from each of five or more colonies), respectively (Cutler, Scott-Dupree \& Drexler, 2014).

Typical clinical symptoms of acute insecti- 
cide poisoning include cramping, disoriented behaviour of bees, and abnormal wing movements. Several intoxication symptoms like cramping, disorientation, locomotion problems, and abdominal spasms of dying bees were observed after bees were exposed to a priori defined $0.25 \mathrm{~g}$ dose of clothianidin in dust per ha (Pistorius et al., 2015). A temporary effect of strong aggressiveness during exposure of bees to clothianidin from dust was also observed (EFSA, 2013a). Because exposure is not uniform for bees, the extent of particular effects will vary. After the intoxication with neonicotinoids, such anomalous behaviour of worker bees as rolling, was observed in $71.4 \%$ of the affected hives, disorientation - in $57.4 \%$, aggressiveness - in $23.8 \%$, and incapability to enter the hive in 52.3\% (Bortolotti et al., 2009). Other authors noticed trembling, tumbling or behaving in an uncoordinated and unsynchronised way after exposure of honeybees to imidacloprid and its metabolites (Suchail, Guez \& Belzunces, 2001a; Medrzycki et al., 2003).

The definition of incident, in many cases is rather conservative, and based on the use of pesticide and not on how many bees, colonies or apiaries were affected. One pesticide application causing bee deaths at several apiaries would be counted as one incident. Incidents often affect up to several hundred honeybee colonies. It was considered a better way to measure the impact of a pesticide, than the total number of suffered colonies (Thompson \& Thorbahn, 2009).

\section{Legislation - monitoring systems}

Within the European Union, monitoring studies are recommended as a complement to risk assessment, according to the Regulation (EC) No 1107/2009. Monitoring is an invaluable tool for verification of the conditions of exposure and the occurrence of risk in the field, as well as the efficiency of risk mitigation measures. In 2010, the EU Commission required Member States to initiate monitoring programmes. The purpose was to verify the real exposure of honeybees to some neonicotinoids (clothianidin, thiamethoxam, imidacloprid) and fipronil, in areas extensively used by bees for foraging or by beekeepers, where and as appropriate (EU,
2010). However, there is no official EU guide for performing monitoring studies for honey bees or other pollinating insects. A review of current methodologies applied in 24 gathered honeybee monitoring studies, was made. The result was that monitoring studies were recommended (Alix \& Garrido, 2015). Despite the fact that many honeybee monitoring studies were to establish the exposure to pesticides, or to perform residue analysis in bee matrices or pollen/nectar/flowers, the proposed recommendations did not include any of these aspects. Thus, the result may be a general lack of data on pesticide concentrations and lack of direct correlation with a particular pesticide or pesticide mixture.

The EU did not establish any system to centralise and publish information on honeybee poisoning. Even in individual Member States, the data are often managed by several different institutions and frequently only with a restricted area of coverage. This leads to a poor, limited distribution of toxicoepidemiological data, with little or no availability for stakeholders or the general public. The United States, in contrast to the EU, established a detailed and comprehensive guide for inspecting alleged cases of pesticiderelated bee incidents (US EPA, 2013). The guide assumes standardising and strengthening the inspections of honeybee death incident, as an important element of the U.S. Environmental Protection Agency's Pollinator Protection Strategic Plan. The guide contains recommendations covering the collection of preliminary information, pre-inspection planning, interviewing the beekeeper, inspecting the hive, inspecting the site of bee deaths, identifying and inspecting potential pesticide sources and separate attachments like sampling and sample analysis, and an example on-site hive inspection checklist. The US guidance is an excellent principle of standardisation for the investigation of honeybee poisoning incidents.

Post-registration surveillance of pesticides has been established to permit reporting of suspected cases of honeybee poisonings and to inform the regulatory process in the UK, Germany, and the Netherlands (Thompson \& 
Thorbahn, 2009). Honeybee pesticide incidents in Canada should be reported directly to the PMRA or alternatively to the pesticide company that is obligated by law to file a report to the PMRA. Reporting to government authorities gives reliable data on honeybee pesticide incidents, and provides valuable feedback on a regulatory system. Government funding usually supports conducting extensive analytical diagnosis of complex situations when information is lacking, when standard toxicological analyses may not be sufficient and further investigation of these incidents may require an additional investment of time and money.

Monitoring systems are varied between countries in terms of: reporting individual cases of poisoning, criteria of identification, categorisation, analytical examination, and interpretation of the results. Above all, the effectiveness of post-registration monitoring of honeybee poisoning depends primarily on the willingness of the beekeepers who suffered honeybee losses. That willingness is correlated with benefits that beekeepers could gain after they gather the investigation results. In view of the important ecological and economic value of bees, there is a need to monitor and maintain healthy bee stocks, not just locally or nationally, but globally. The production of $84 \%$ of crop species cultivated in Europe, depends directly on insect pollinators, especially bees (Klein et al., 2007).

\section{Interpretation of the analytical results - toxicity of pesticides}

The main evidence of the involvement of certain active substances in the poisoning of honeybees, is the residue found in the sample of dead bees. The incidents were attributed to pesticides when pesticide residues were detected in bees and other related materials, such as plants on which the bees had been foraging (Thompson \& Thorbahn, 2009). This interpretation is correct in reference to acute contact poisoning incidents. But the investigation of poisoning related to systemic pesticides needs knowledge that previous seed treatment could be source of secondary poisoning through contaminated pollen, nectar, and guttation water. Not only is the presence of pesticide residue detected in collected samples essential for an interpretation, but in many cases also the level of concentration. The significance of a result is assessed primarily against: published toxicity data, other supporting field information, and/or experience of previous incidents. A specific decisive threshold does not exist, although a study utilising honeybees as bioindicators could be helpful provided that the scope of the analytical methods do not focus mainly on active substances withdrawn from use many years ago (Bargańska, Ślebioda \& Namieśnik, 2016). Within the UK, an incident is attributed to pesticide poisoning if the residue is close to or above the median lethal dose $L_{50}$ or 'subsequent residue level' (Fletcher \& Barnett, 2003). Interpretation of the result is often clear-cut (a large positive or a negative result). Sometimes, in the case of small residues (usually when the victim has taken a long time to die), conclusions are based on the combined power of field, veterinary, and analytical evidence, interpreted on the basis of more than 30 years of investigations, in addition to published and experimental data (Brown et al., 2005). Recent studies emphasised that 'the formulation and not just the dose makes the poison' (Mullin et al., 2015), and that a lack of disclosure of formulation ingredients in major products limits risk analysis (Mullin, 2015). It was stated, that formulation will likely be a major influence in affecting both the toxicity and the environmental fate of pesticides. Also stated, is that toxicity and physicochemical properties obtained for the active ingredients are a source of serious limitation (Mineau et al., 2008). On the risk assessment of bees, EFSA suggested that studies with the formulation are only required for spray application (Tab. 1), but only if the toxicity of the formulation cannot be predicted on the basis of the active substance.

A comprehensive review of $L_{50}$ or $L C_{50}$ values gathered from the Pesticide Manual (Tomlin, 2009), the ECOTOX database of the U.S. EPA, and the Agri-Tox Database of the ANSES in France, has already been done (Sanchez-Bayo \& Goka, 2014). This review included data for $76 \%$ 
The recommendations of required studies on the active substance or formulation (EFSA, 2013)

\begin{tabular}{ccc}
\hline Application method & $\begin{array}{c}\text { Study with active } \\
\text { substance required }\end{array}$ & $\begin{array}{c}\text { Study with formulation } \\
\text { required }\end{array}$ \\
\hline Acute oral & $\begin{array}{c}\text { Yes -always required } \\
\text { If exposure to spray } \\
\text { deposits are likely, then } \\
\text { required }\end{array}$ & $\begin{array}{c}\text { Yes } \\
\text { If exposure to spray } \\
\text { deposits are likely, then } \\
\text { required }\end{array}$ \\
Chronic oral toxicity to \\
adults & Yes & No \\
Toxicity to larvae & Yes & No \\
\hline Acute oral & Solid & No \\
Acute contact & Yes & No \\
If exposure to spray & deposits are likely, then \\
required & Yes & No \\
Toxicity to larvae & Yes & No
\end{tabular}

of the existing insecticides and fungicides and $83 \%$ of acaricides, registered for use in agriculture.

Finally, it should be noted that the $\mathrm{LD}_{50}$ and $\mathrm{LC}_{50}$ illustrates the toxic dose and not the residue in honeybees. For this reason, the $L_{50}$ and $L C_{50}$ cannot be used as decisive threshold values for making a statement about whether the concentration found in dead honeybees clearly indicates poisoning. Little is known about the persistence of pesticides in apicultural matrices kept under field conditions. The residue detected in bees is low compared to the $L D_{50^{\prime}}$ probably because of pesticide degradation due to the exposure to field conditions (humidity, light and temperature variation). The decomposition of some pesticides in dead honeybees as well as plant samples was investigated, but such data are extremely limited (Kamler et al., 2003; Laurino et al., 2011; DEFRA, 2014). The half-life studies showed that there was slower penetration of the waxy insect cuticule by lipophobic pesticides (DEFRA, 2014). An example that lipophobic (clo- thianidin) and lipophilic (chlorpyrifos) properties show a clear impact in contact absorption of active substances, is shown on Fig. 2 .

This could also mean that contact toxicity of other lipophobic pesticides could be underestimated and uncertain, and surfactants, penetrant enhancers, spreaders, stickers etc. have a huge impact on the toxicity of active ingredients and should be mandatory included in the risk assessment. Producers of PPPs in formulations, use auxiliary organic solvents such as aromatics, chlorinated aromatics or chlorinated aliphatic hydrocarbons, mineral oil fractions etc. The standardise method for studying acute contact pesticide toxicity towards Apis mellifera presupposes that the test substance be preferably applied as a solution in acetone or as a water solution with a wetting agent (Medrzycki et al., 2013). Other organic solvents of low toxicity to bees may be used but they must be administered in the negative reference. The acetone or water is only one of the pluralities of organic solvents used in pesticide formulations and in the light of 

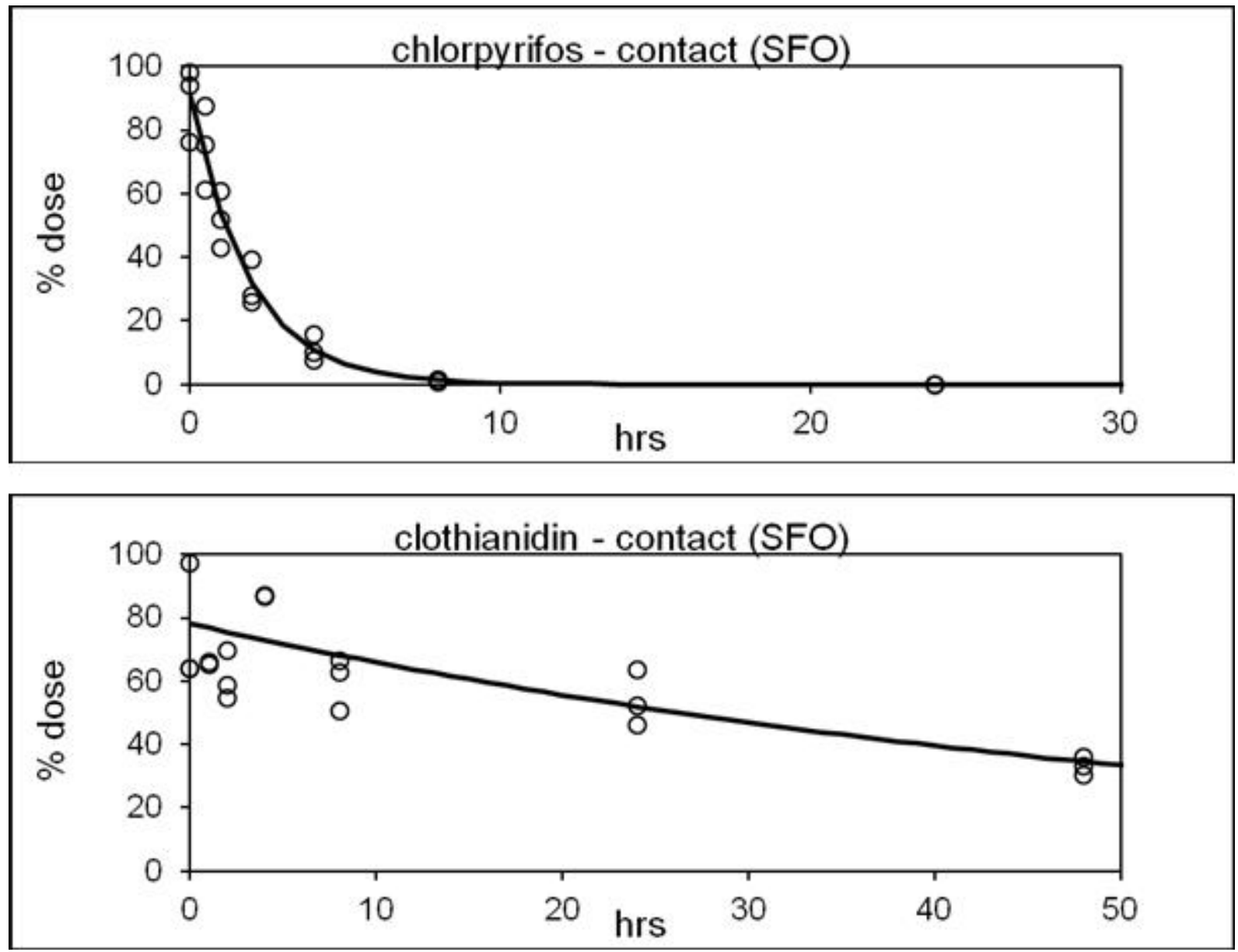

Fig.2

Plots of percentage of dose measured with respect to time after dosing (from DEFRA, 2014).

the other above arguments, they do not reflect reality. The external waxy layer of insect epicuticule creates a barrier for polar solvents and lipophobic active substances. In such cases the toxicity of a formulation cannot be predicted on the basis of the active substance test.

\section{Analytical methods}

As with the monitoring systems and the definition of an incident, there are also differences in the approaches with pesticide residue analysis. A common goal is to investigate a poisoning incident and take samples as soon as possible.

The range of investigated compounds is different within different monitoring schemes. A review of those chromatographic methods published up till now, of pesticide residues analysis in honeybees, is already available (Kiljanek et al., 2016). These methods differ by the number of analysed pesticides and by the share of currently approved active ingre- dients. In Germany, herbicides and fungicides were routinely screened and used as a 'fingerprint' to establish a link between bee and plant material, whilst in the UK, fungicides and herbicides were only screened when field evidence suggested that they may be implicated (Thompson \& Thorbahn, 2009). Recent studies showed that an average of four pesticides were determined in poisoned honeybee samples, and up to thirteen pesticides were simultaneously detected (Kiljanek et al., 2016). In the UK, imidacloprid or ergosterol biosynthesis inhibition (EBI) fungicides, are only sometimes considered in the testing (Barnett, Charlton \& Fletcher, 2007), and pesticide mixtures were found only in 4\% of incidents between 1994 and 2003 (Thompson \& Thorbahn, 2009). The multi-residue analysis results in a more complete picture of the possible reasons of poisoning, and makes it possible for an effective investigation even when there are limited initial data about the 


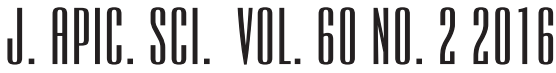

application of a specific PPP. Furthermore, the synergism between fungicides and insecticides occurs and is widely patented by chemical companies. Ergosterol-biosynthesis-inhibiting fungicides could repeatedly increase the toxicity of insecticides (Iwasa et al., 2004).

In Germany, before chemical analysis, a biotest of contact toxicity with bee samples and larvae of Aedes aegypti is undertaken. The biotest was positive in $91.4 \%$ of the samples of honeybee poisoned with clothianidin (Pistorius et al., 2009). Bee samples often are also screened for common biological agents that in some periods of a year could be mortality factors as it is shown on Fig. 3. Visual inspection and microscopic examination of stomach contents and tested objects such as pollen, beebread, nectar, and guttation water. The analysis of beebread may be underestimated, since it is most likely that individual pollen layers in a cell show a variation of the residue content, and partial contamination cannot be detected (Pistorius et al., 2009).

Pesticide concentrations in poisoned honeybee samples

One of the main goals of this review was to collect already published data from different countries, that may illustrate the problem of honeybee poisoning with pesticides. The range of detected pesticides and concentrations of particular pesticides, in poisoned honeybee samples are compiled in Tab. 2. Some publica-

\section{Causal complex depends on the period}

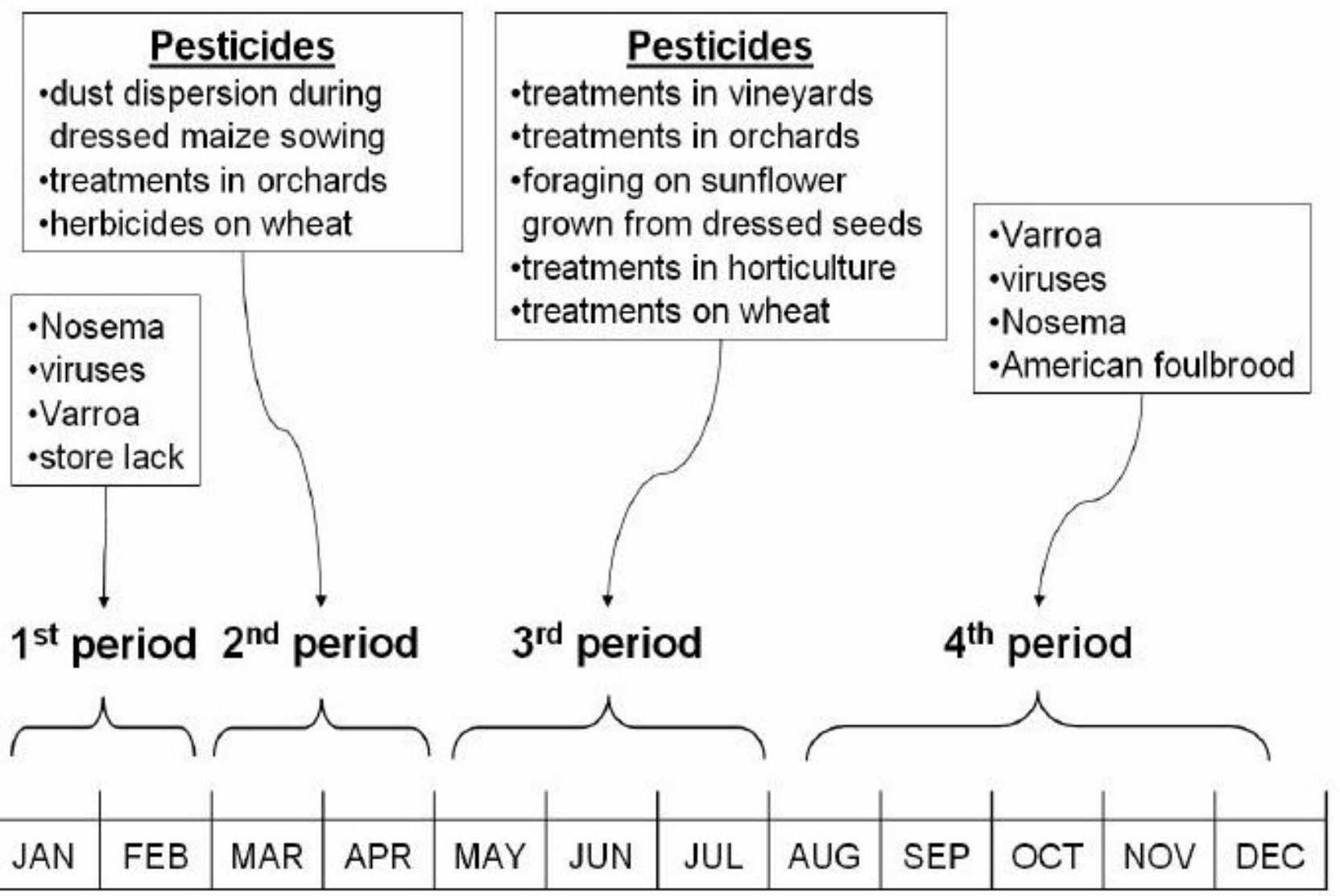

Fig. 3

Main mortality factors affecting honeybees in northern Italy (from Maini et al., 2010).

bee parts could also be conducted, as well as paIynological analysis of the origin of the pollen in the body hair and pollen basket loads (Pistorius et al., 2009).

The analysis of systemic pesticides should be as sensitive as possible to meet the challenges of tions only made available data that could help in establishing the frequency of honeybee poisonings with a particular insecticide (Barnett, Charlton \& Fletcher, 2007; Bischoff et al., 2010). Collected data are often obviously limited to the capabilities of the analytical method used. 
Table 2

Range of pesticides and their concentrations detected in poisoned honeybee samples

\begin{tabular}{|c|c|c|c|}
\hline Detected pesticides & $\begin{array}{l}\text { Number of } \\
\text { samples }\end{array}$ & Concentration range $(\mathrm{ng} / \mathrm{g})$ & Reference \\
\hline Clothianidin & 27 & $3.6-39.2$ & \multirow{3}{*}{ Bortolotti et al., 2009} \\
\hline Imidacloprid & 27 & $1.0-240.6$ & \\
\hline Thiamethoxam & 3 & $24.8-138$ & \\
\hline Clothianidin & 71 & $1-212.2$ & \multirow{2}{*}{ Pistorius et al., 2009} \\
\hline Methiocarb & 25 & $1-20$ & \\
\hline Clothianidin & 2 & 1.2 & Nikolakis et al., 2009 \\
\hline Tebuconazole & 12 & $10-1146$ & \multirow{10}{*}{ Walorczyk \& Gnusowski, 2009} \\
\hline Omethoate & 11 & $93-1156$ & \\
\hline Fipronil & 10 & $10-64$ & \\
\hline Dimethoate & 9 & $238-4864$ & \\
\hline Vinclozolin & 8 & $185-657$ & \\
\hline Chlorpyrifos & 5 & $10-56$ & \\
\hline Fenitrothion & 2 & $473-963$ & \\
\hline Boscalid & 1 & 33 & \\
\hline Phosalone & 1 & 66 & \\
\hline Prochloraz & 1 & 412 & \\
\hline Clothianidin & 1 & 1.8 & $\begin{array}{c}\text { Chauzat et al., } \\
2010\end{array}$ \\
\hline Zeta-cypermethrin & 11 & $90-5910$ & \multirow{17}{*}{ Łozowicka, 2013} \\
\hline Chlorpyrifos & 9 & $10-576576$ & \\
\hline Bifenthrin & 7 & $20-130$ & \\
\hline Cypermethrin & 4 & $29-6300$ & \\
\hline Dimetoate & 4 & $11-7280$ & \\
\hline Tebuconazole & 4 & $60-1780$ & \\
\hline Fipronil & 3 & $8-17$ & \\
\hline Alpha-cypermethrin & 2 & $40-1344$ & \\
\hline Chlorothalonil & 1 & 11 & \\
\hline$p, p^{\prime}-D D E$ & 1 & 90 & \\
\hline $0, p^{\prime}-D D T$ & 1 & 30 & \\
\hline $\mathrm{p}, \mathrm{p}^{\prime}-\mathrm{DDT}$ & 1 & 80 & \\
\hline Dichlorvos & 1 & 302 & \\
\hline Gamma-HCH & 1 & 10 & \\
\hline Lambda-cyhalothrin & 1 & 110 & \\
\hline Permethrin & 1 & 15650 & \\
\hline Phosalone & 1 & 235 & \\
\hline Clothianidin & 21 & $0.7-39.9$ & \multirow{12}{*}{ Kasiotis et al., 2014} \\
\hline Chlorpyrifos & 4 & $<L O Q-46$ & \\
\hline Thiamethoxam & 4 & $0.5-49.6$ & \\
\hline Coumaphos & 2 & $<L O Q-20.3$ & \\
\hline Imidacloprid & 2 & $0.3-5.7$ & \\
\hline Fipronil & 1 & 81.5 & \\
\hline Fipronil sulfone & 1 & 79.1 & \\
\hline Indoxacarb & 1 & 15.2 & \\
\hline Penconazole & 1 & 47.4 & \\
\hline Phoxim & 1 & 750 & \\
\hline Thiacloprid & 1 & $<\mathrm{LOQ}$ & \\
\hline Trifloxystrobin & 1 & 58 & \\
\hline Chlorpyrifos & 16 & $2-220$ & \multirow{11}{*}{ Porrini et al., 2014} \\
\hline Fenitrothion & 11 & $22-6999$ & \\
\hline Pirimiphos-methyl & 10 & $1-42$ & \\
\hline Dimethoate & 6 & $10-40$ & \\
\hline Chlorpyrifos-methyl & 3 & $5-492$ & \\
\hline Cypermethrin & 1 & 26855 & \\
\hline Diazinon & 1 & 46 & \\
\hline Malathion & 1 & 74 & \\
\hline Omethoate & 1 & 63 & \\
\hline Parathion & 1 & 6 & \\
\hline Parathion-methyl & 1 & 1 & \\
\hline
\end{tabular}




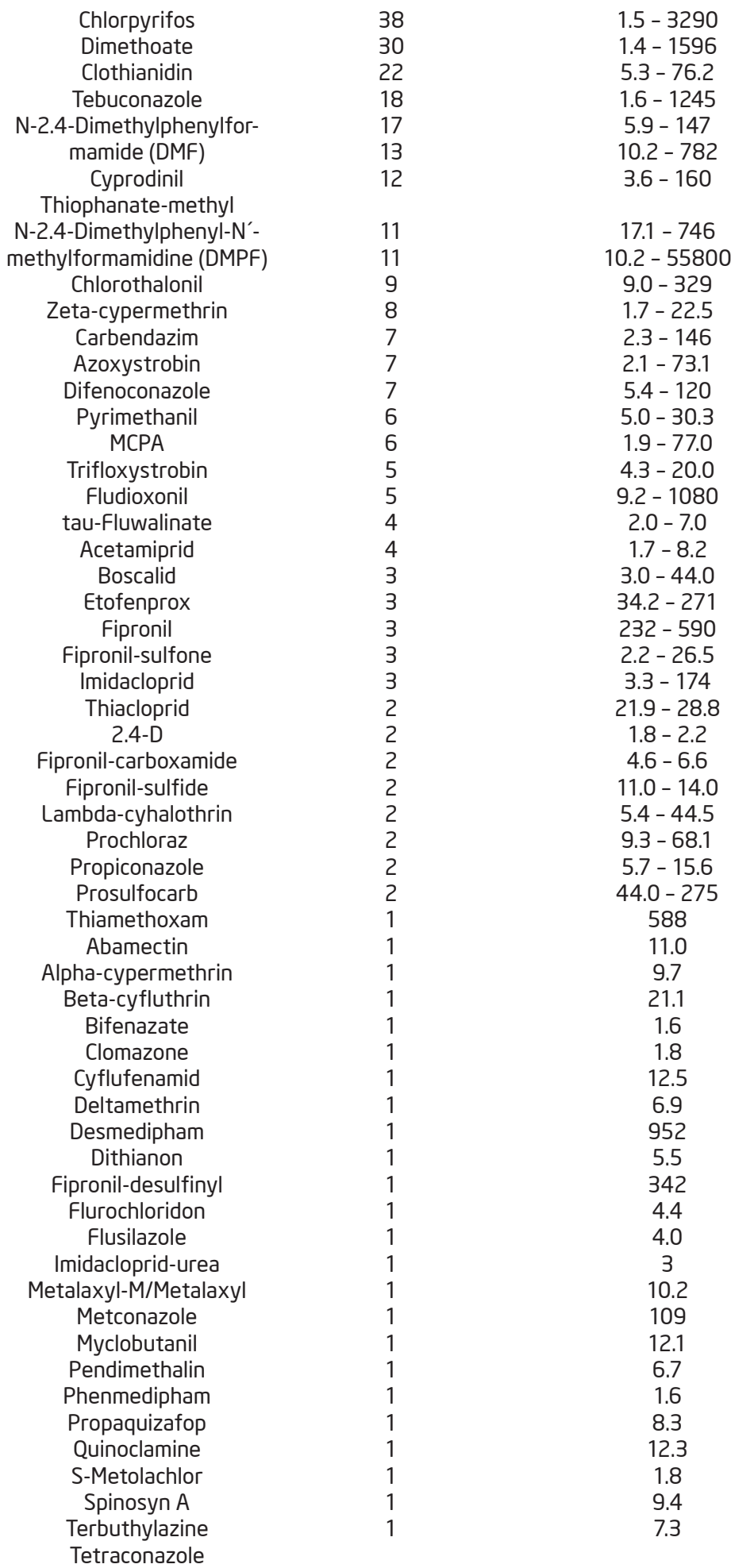

Kiljanek et al., 2016
Some compounds, due to their physicochemical properties, could only be analysed with gas or liquid chromatography. Only methods utilizing both gas and liquid chromatography could analyse the whole range of pesticides that create a main risk for honeybees.
Neonicotinoid poisoning of honeybees Clothianidin is the active ingredient established as a cause of most of the investigated honeybee poisoning incidents. Clothianidin was detected in at least 217 dead bee samples (Tab. 2). The concentrations of clothianidin in dead honeybees ranged from 0.5 to $212.2 \mathrm{ng} / \mathrm{g}$. The data from 
monitoring healthy honeybee colonies showed a maximum clothianidin residue of $0.65 \mathrm{ng} / \mathrm{g}$ (DEFRA, 2014). A concentration of about 0.5 $\mathrm{ng} / \mathrm{g}$, or to be more certain $1 \mathrm{ng} / \mathrm{g}$ of clothianidin found in poisoned honeybees, could indicate that this active ingredient was the cause of death. This extreme poisoning risk of clothianidin is well documented by mortality and residue data available from controlled experiments, as shown in Fig. 4 and Fig. 5, respectively.
(Nikolakis et al., 2009) . The concentration of clothianidin in dead bees at a level of $1.2 \mathrm{ng} / \mathrm{g}$ indicates poisoning. It should be reconsider that honeybees could be secondarily poisoned when being exposed to systemic residues of clothianidin within pollen, nectar, and guttation water. The secondary poisoning with systemic residues of clothianidin confirms the report that sub-lethal exposure of systemic neonicotinoids affects the winterization of healthy colonies

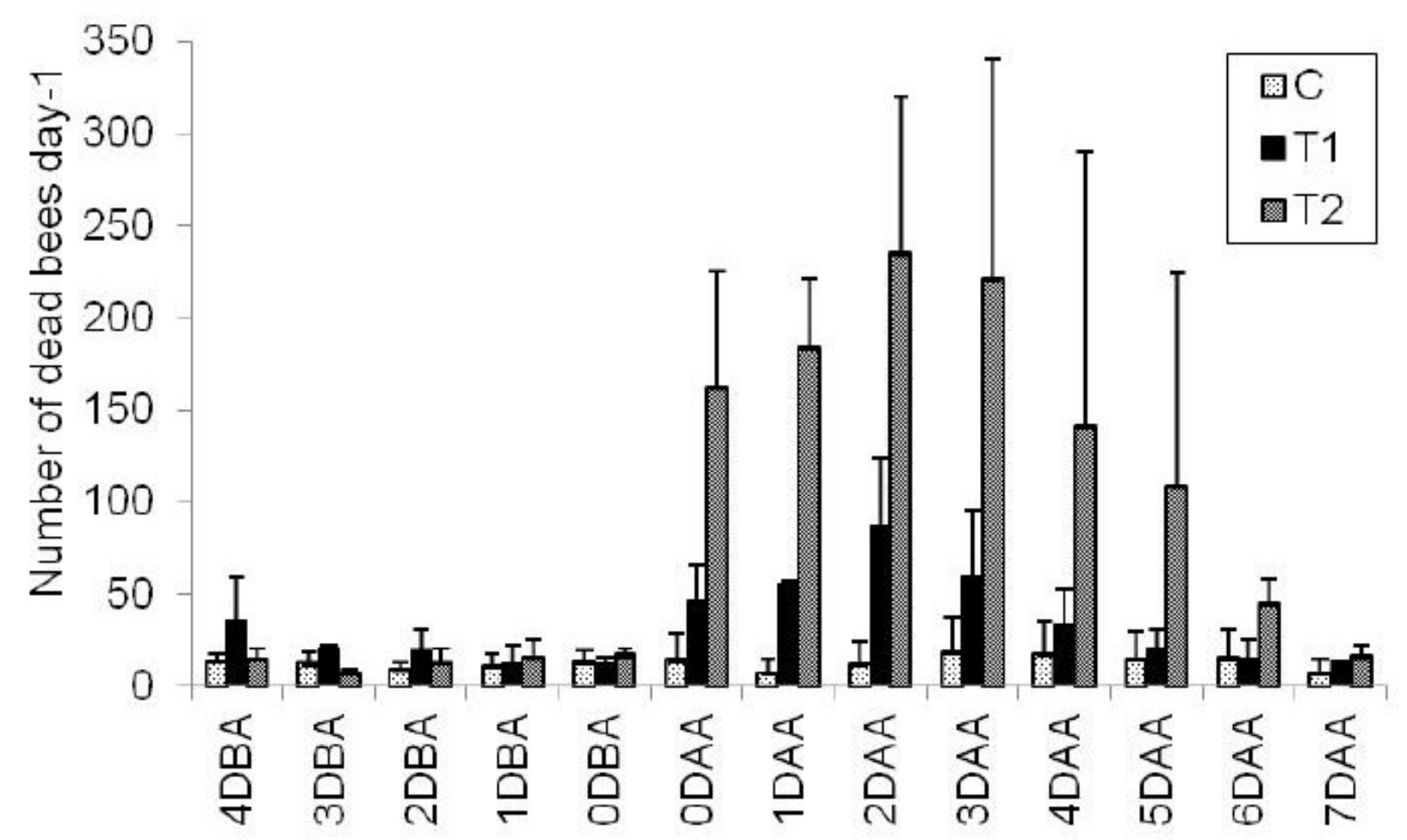

Days before (DBA) / after (DAA) Application

Fig. 4

Mean number of dead worker bees per day before and after application of dust with clothianidin formulation (from Pistorius et al., 2015).

It is a far reaching conclusion that systemic residues of clothianidin do not pose a risk to bee colonies and that the colonies are not exposed a second time to their harmful levels. The results of honeybee colonies health monitoring program conducted during plant growing season in Germany, in the areas where spring honeybee poisonings related to contaminated dust accompanying sowing occurred, showed only two samples of dead bees with clothianidin residues at the level of $1.2 \mathrm{ng} / \mathrm{g}$ and it is the secondary poisoning that subsequently leads to CCD (Lu, Warchol \& Callahan, 2014).

Other neonicotinoids such as imidacloprid and thiamethoxam were also detected in poisoned honeybees. The detected imidacloprid concentrations were from 0.3 to $240.6 \mathrm{ng} / \mathrm{g}$. Accordingly, thiamethoxam was detected in concentrations from 0.5 to $275 \mathrm{ng} / \mathrm{g}$. Other neonicotinoids such as thiacloprid and acetamiprid were also determined. 


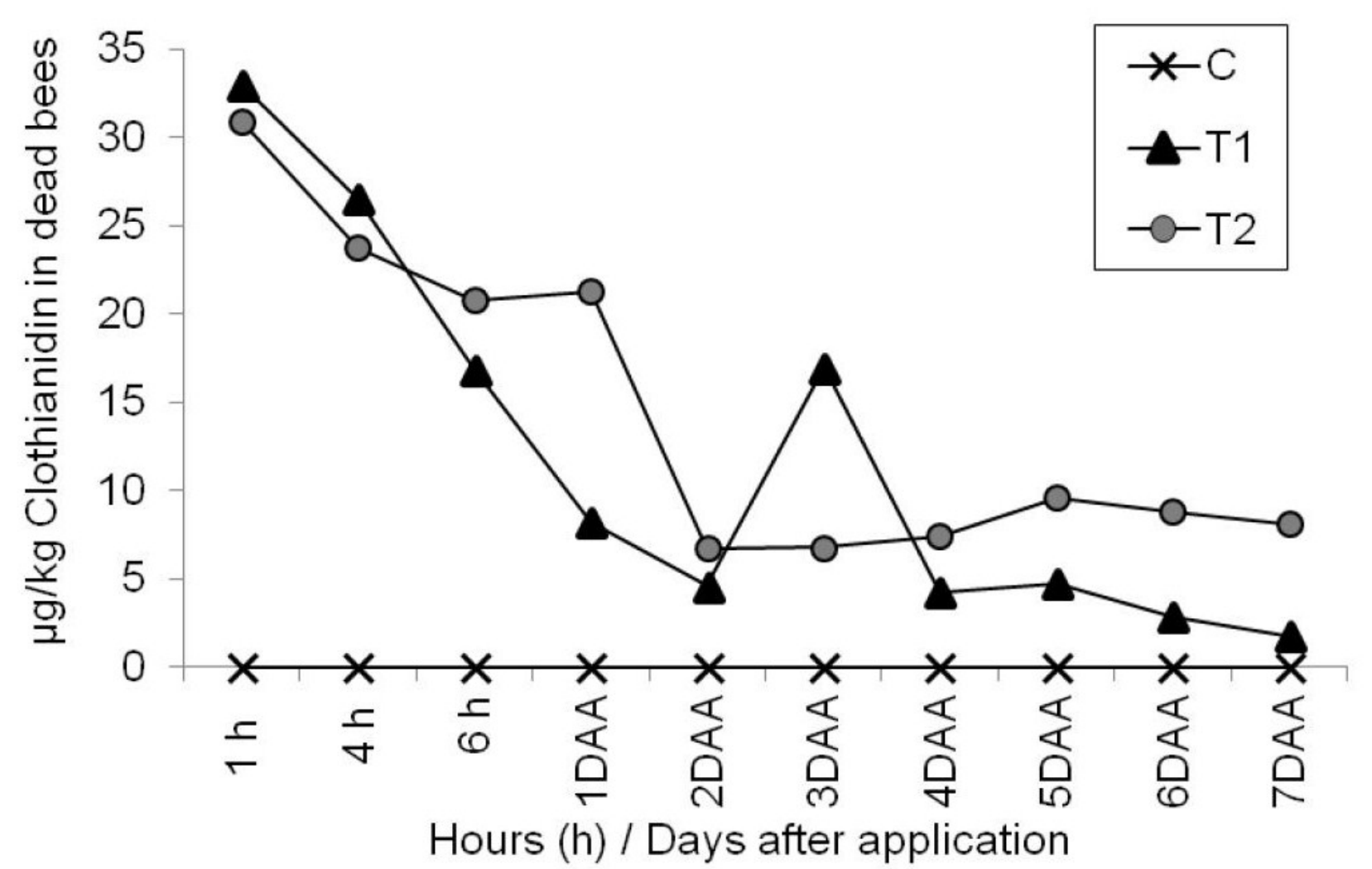

Fig. 5

Residues in dead bees from traps in control, test item treatment $\mathrm{T} 1$ and $\mathrm{T} 2$ after application of dust with clothianidin formulation (from Pistorius et al., 2015).

\section{Fipronil poisoning of honeybees}

Fipronil, the active substance banned as a seed treatment within the EU (EU, 2013), similarly three neonicotinoids (EU, 2013a), was detected in 54 honeybee poisoning cases. The concentrations ranged from 8 to $271 \mathrm{ng} / \mathrm{g}$ (Tab. 2). It was found that fipronil quickly converts to fipronil sulfone, which has a similar toxicity and could possibly accumulate in foraging bees exposed to multiple sub-acute doses over several days (DEFRA, 2014). In the summaries of almost all the incidents of honeybee poisonings gathered by EFSA, the conclusions are, that although fipronil and its metabolite were detected in the bee samples, fipronil and its metabolite were never detected in plants and that is why bee losses were correlated to 'other' factors (EFSA, 2013b). Fipronil was allowed for use during seed treatment, soil treatment, and as a biocide, and it was difficult to link the results with the uses. In more than $70 \%$ of honeybee poisoning cases investigated in Hungary, the link between the pesticide application and honeybee poisoning could not be established. Nonetheless it was concluded that the most severe impact on the colonies was observed in the fipronil cases (Fazekas et al., 2012). Generally the sources of fipronil honeybee poisoning were unknown and considered to be 'other'. In Poland, the poisoning of honeybees occurred in the early autumn, and it was not connected with any spray application. An investigation demonstrated that the poisoned hives were located in the neighbourhood of cauliflower plantings. The EU allowed fipronil as a seed treatment for the group of Brassica vegetables intended to be sown in fields and harvested before flowering (EU, 2013). In such a case, the source of honeybee poisoning could be guttation water and/or pollen contaminated with systemic fipronil from the seed treatment. Guttation drops can be contaminated with systemic neonicotinoids in concentrations near those applied during field sprays, or 
even higher (Girolami et al., 2009). Surprisingly, fipronil was never detected in guttation drops (Bonmatin et al., 2015) though it was reported as one of the most frequent residues found in pollen in France (Chauzat et al., 2006, 2009, 2011). The cause could be that only fipronil but not its metabolites (which are known to be of the same toxicity to honeybees as the parent substance), were examined in guttation water till now (Tapparo et al., 2011). In autumn, the water demand of honeybee colonies is almost exclusively covered by guttation water collection (Reetz et al., 2012). The poisoning of honeybees foraging cauliflower in the early autumn could be a perfect example of secondary poisoning.

\section{Organophosphorus pesticide poisoning and} pyrethroid poisoning of honeybees

Chlorpyrifos is the second most commonly quantified pesticide in poisoned honeybee samples. Chlorpyrifos was measured in concentrations from 1.5 to $576576 \mathrm{ng} / \mathrm{g}$ (Tab. 2). Other organophosphorus pesticides like dimethoate, and its metabolite omethoate, were detected in concentrations from 1.4 to $7280 \mathrm{ng} / \mathrm{g}$ and 63 to $1156 \mathrm{ng} / \mathrm{g}$, respectively. Organophosphorus pesticides lead to many honeybee poisoning incidents.

Pyrethroids like the isomers of cypermethrin, lambda-cyhalothrin, bifenthrin, and deltamethrin, were detected in a total of 81 honeybee poisoning cases (Tab. 2). Maximum pyrethroid residues, with the exception of cypermethrin, were approximately two times lower than neonicotinoid residues and much less than concentrations of organophosphorus pesticides. Pyrethroids have a quick knockdown effect. This means that bees would be more likely to die away from the hive and not be reported. Additionally, pyrethroids have a low application rate which could result in very small concentrations of the pyrethroids in dead bees, and could result in the under-reporting of poisoning incidents (Mineau et al., 2008).

\section{Conclusion}

Neonicotinoids and fipronil are first systemic insecticides. Neonicotinoids toxicity against honeybees could be underestimated. Because neonicotinoids have systemic and hydrophilic properties, they can persist in plant matter. This ability causes an extreme risk of acute toxicity and also secondary poisoning and sub-poisoning of winter honeybees which are dependent on a very limited source of food. Poisoning, secondary poisoning or sub-poisoning probably cause colony collapse disorder. Gradually eating toxic food could lead winter bees to exceed the toxic level. The bees then lose proper functioning of the nervous system and lose appropriate behaviour during the winterising period. The absence of the proper fulfilment of social functions assigned to the different castes of bees consequently leads to extinction of the superorganism. A strong colony becomes somewhat victim to the well-being of plants and collection of large stocks of food. In the winter it is not possible to get rid of the bees which are 'disobeying the queen' and to replace these bees with new, useful copies. Systemic pesticides most likely cause secondary systemic poisoning.

Fungicides, particularly systemic ones, as well as insecticides, could play a synergistic role in sub-poisoning. A clearly significant positive relationship between the probability of a colony showing disorders and the total number of fungicides, has been discovered (Simon-Delso et al., 2014). Midgut metabolism is important in the detoxification of chemicals in the honeybee. Therefore, the health of the midgut is key in the detoxification following oral exposure (Thompson et al., 2014). Fungicides may have an impact on the colony since they modify the existing microflora present in the beebread (DeGrandi-Hoffman, Chen \& Simonds, 2013; Yoder et al., 2013) or because they modify existing microflora in the bee intestinal tract (Batra, Batra \& Bohart, 1973; Anderson et al., 2011). Thus, fungicide residues could impair detoxification of systemic insecticides administered orally with beebread. The model explaining the delayed and time-cumulative toxicity of imidacloprid, based on its mode of action, already exists (Rondeau et al., 2014). Honeybees are at risk of 'modern' systemic pesticides. Pre-registration risk assessment 
addresses the sources of risks very well. But, the protection of honeybees also needs a 'systemic' approach and not only already worked-out solutions. Systemic clothianidin is a top insecticide causing acute honeybee poisonings in Europe and North America. Risk of secondary poisonings or sub-poisoning which is most probably the CCD phenomenon, needs to be globally and comprehensively managed and resolved. The honeybee poisoning investigation systems, worked out on the basis of experiences with 'traditional' contact poisoning, are unable to investigate secondary poisoning or sub-poisoning from systemic pesticides. The fate of honeybees is inextricably linked with the fate of pest insects such as aphids and diseases transferred by the pests, such as the barley yellow dwarf virus (BYDV). Fighting against this virus carried out by combating aphids has already been identified as a possible source for another massive honeybee poisoning incident.

\section{REFERENCES}

AAAS, American Association for the Advancement of Science (2013). Infographic: Pesticide Planet. Science, 347(6147), 728-731. http://dx.doi. org/10.1126/science.341.6147.730

Akratanakul, P. (1990). Pesticides and beekeeping. In Beekeeping in Asia. Rome: FAO Agricultural Services Bulletin 68/4.

Alix, A., \& Garrido, C. (2015). Monitoring effects of pesticides on pollinators - a review of methods and outcomes by the ICPPR working group. JuliusKühn Archiv, 450, 284-295.

Anderson, K.E., Sheehan, T.H., Eckholm, B.J., Mott, B.M., DeGrandi-Hoffman, G. (2011). An emerging paradigm of colony health: microbial balance of the honey bee and hive (Apis mellifera). Insectes Sociaux, 58, 431-444. DOl: 10.1007/s00040-0110194-6

Atkins, E.L. (1992). Injury to honey bee poisoning. In The Hive and the Honey Bee. (pp. 1153-1208).
Illinois: Dadant and Sons Inc.

Batra, L.R., Batra, S.W.T., \& Bohart, G.E. (1973). The mycoflora of domesticated and wild bees (Apoidea). Mycopathologia et mycologia applicate, 49, 13-44. DOl: 10.1007/BF02057445

Bargańska, Ż., Ślebioda, M., \& Namieśnik, J. (2016). Honey bees and their products - bioindicators of environmental contamination. Critical Reviews in Environmental Science and Technology, 46(3), 235-248. DOl: 10.1080/10643389.2015.1078220

Barnett, E.A., Charlton, A.J., \& Fletcher, M.R. (2007). Incidents of bee poisoning with pesticides in the United Kingdom, 1994-2003. Pest Management Science, 63, 1051-1057. DOI: 10.1002/ps.1444

Belzunces, L.P., Tchamitchian, S., \& Brunet, J.L. (2012). Neural effects of insecticides in the honey bee. Apidologie, 43(3), 348-370. DOl: 10.1007/ s13592-012-0134-0

Bischoff, G., Jänicke, K., Nowak, H., Riedel, J. (2010). Chemical bee investigation - Details of the new procedure and selected results since 2008. Retrieved March 30, 2016, from http://bienen.jki. bund.de/dokumente/upload/bedbd_57_dpst_berlin_2010_poster_200_bu_bischoff.pdf

Blacquiére, T., Smagghe, G., van Gestel, C.A.M., Mommaerts, V. (2012). Neonicotinoids in bees: a review on concentrations, side-effects and risk assessment. Ecotoxicology, 27, 973-992. DOl: 10.1007/ s10646-012-0863-x

Bonmatin, J.-M., Giorio, C., Girolami, V., Goulson, D., Kreutzweiser, D.P., Krupke, C., ... Tapparo, A. (2015). Environmental fate and exposure; neonicotinoids and fipronil. Environmental Science and Pollution Research International, 22, 35-67. http://doi. org/10.1007/s11356-014-3332-7

Bortolotti, L., Sabatini, A.G., Mutinelli, F., Astuti, M., Lavazza, A., Piro, R., ... Porrini, C. (2009). Spring honey bee losses in Italy. Julius-Kühn Archiv, 423, 148-152. 
Brown, P.M., Turnbull, G., Charman, S., Charlton, A.J.A., Jones, A. (2005). Analytical methods used in the United Kingdom Wildlife Incident Investigation Scheme for the detection of animal poisoning by pesticides. Journal of AOAC International, 88(1), 204-220.

Cresswell, J.E. (2011). A meta-analysis of experiments testing the effects of a neonicotinoid insecticide (imidacloprid) on honey bees. Ecotoxicology, 20, 149-157. DOl: 10.1007/s10646-010-0566-0

Cutler, G.C., Scott-Dupree, C.D., \& Drexler, D.M. (2014). Honey bees, neonicotinoids and bee incident reports: the Canadian situation. Pest Management Science, 795), 779-783. DOl: 10.1002/ ps.3613

Chauzat, M.P., Faucon, J. P., Martel, A.C., Lachaize, J., Cougoule, N., \& Aubert, M. (2006). A survey of pesticide residues in pollen loads collected by honey bees in France. Journal of Economic Entomology, 99(2), 253-262.

Chauzat, M.P., Carpentier, P., Martel, A.C., Bougeard, S., Cougoule, N., Porta, P., Lachaize, J., Madec, F., Aubert, M., \& Faucon, J. P. (2009). Influence of pesticide residues on honey bee (Hymenoptera: Apidae) colony health in France. Environmental Entomology, 38(3), 514-523.

Chauzat, M.P., Martel, A.C., Blanchard, P., Clément, M.C., Schurr, F., ... Faucon, J.P. (2010). A case report of a honey bee colony poisoning incident in France. Journal of Apicultural Research, 49(1), 113-115. http://dx.doi.org/10.3896/IBRA.1.49.1.22

Chauzat, M.P., Martel, A.C., Cougoule, N., Porta, P., Lachaize, J., Zeggane, S., ... Faucon, J.P. (2011). An assessment of honeybee colony matrices, Apis mellifera (Hymenoptera Apidea) to monitor pesticide presences in continental France. Environmental Toxicology and Chemistry, 3a1), 103-111. DOl: 10.1002/etc.361

Claudianos, C., Ranson, H., Johnson, R.M., Biswas, S., Schuler, M.A., Barenbaum, M.R., ... Oakeshott, J.G. (2006). A deficit of detoxification enzymes: pesti- cide sensitivity and environmental response in the honeybee. Insect Molecular Biology, 15(5), 615636. DOl: 10.1111/j.1365-2583.2006.00672.x

DEFRA (Department for Environment Food and Rural Affairs). (2014). Evidence Project Final Report. Defra Project code PS2370. Interpretation of pesticide residues in honey bees. Retrieved April 05, 2016, from http://randd.defra.gov.uk/Default. aspx?Menu=Menu\&Module=More\&Location=Non e\&ProjectID=18321

DeGrandi-Hoffman, G., Chen, Y., \& Simonds, R. (2013). The effects of pesticides on queen rearing and virus titers in honey bees (Apis mellifera L.). Insects, 4, 71-89. D0l:10.3390/insects4010071

Desneux, N., Decourtye, A., Delpuech, J.-M. (2007). The sublethal effects of pesticides on beneficial arthropods. Annual Review of Entomology, 52, 81-106. DOl: 10.1146/annurev. ento.52.110405.091440

EFSA (European Food Safety Authority). (2013). Guidance on the risk assessment of plant protection products on bees (Apis mellifera, Bombus spp. and solitary bees). EFSA Journal 77(7), 3295. DOl: 10.2903/j.efsa.2013.3295

EFSA (European Food Safety Authority). (2013a). Conclusion on the peer review of the pesticide risk assessment for bees for the active substance clothianidin. EFSA Journal, 77(1), 3066. D0l:10.2903/j. efsa.2013.3066

EFSA (European Food Safety Authority). (2013b). Conclusion on the peer review of the pesticide risk assessment for bees for the active substance fipronil. EFSA Journal, 77(5), 3158. DOl:10.2903/j. efsa.2013.3158

Ensley, S.M. (2012). Neonicotinoids. In Veterinary Toxicology. (pp. 596-598). San Diego: Elsevier Academic Press. DOl:10.1016/B978-0-12-3859266.00048-X

EU (European Union). (2010). Commission Directive 2010/21/EU of 12 March 2010 amending Annex 
I to Council Directive 91/414/EEC as regards the specific provisions relating to clothianidin, thiamethoxam, fipronil and imidacloprid. Official Journal of the European Union, 65, 13.3.2010, 27-30.

EU (European Union). (2013). Commission Implementing Regulation (EU) No 781/2013 of 14 August 2013 amending Implementing Regulation (EU) No 540/2011, as regards the conditions of approval of the active substance fipronil, and prohibiting the use and sale of seeds treated with plant protection products containing this active substance. Official Journal of the European Union, 219, 15.8.2013, 22-25.

EU (European Union). (2013a). Commission Implementing Regulation (EU) No 485/2013 of 24 May 2013 amending Implementing Regulation (EU) No 540/2011, as regards the conditions of approval of the active substances clothianidin, thiamethoxam and imidacloprid, and prohibiting the use and sale of seeds treated with plant protection products containing those active substances. Official Journal of the European Union, 139, 25.5.2013, 12-26.

Fazekas, B., Woynárovichné Láng, M., Deákné Paulus, P., Csaba, G., Orosz, E. (2012). Pesticide poisoning of honey bees between 2007 and 2011. Magyar Allatorvosok Lapja, 134(4), 213-220.

Fletcher, M., \& Barnett, L. (2003). Bee pesticide poisoning incidents in the United Kingdom. Bulletin of Insectology, 56(1), 141-145.

Girolami, V., Mazzon, L., Squartini, A., Mori, N., Marzaro, M., Di Bernardo, A., ... Tapparo, A. (2009). Translocation of neonicotinoid insecticides from coated seeds to seedling guttation drops: A novel way of intoxication for bees. Journal of Economic Entomology, 102(5), 1808-1815.

Iwasa, T., Motoyama, N., Ambrose, J.T., Roe, R.M. (2004). Mechanism for the differential toxicity of neonicotinoid insecticides in the honey bee, Apis mellifera. Crop Protection, 23(5), 371-378. DOl: 10.1016/j.ссорго.2003.08.018
JKI (Julius Kühn-Institut). (2010). Untersuchungsstelle für Bienenvergiftungen. Retrieved March 31, 2016, from http://bienen.jki.bund.de/dokumente/upload/311d5_antrag_jki_2010_v4_27_ mai_2010_online.pdf

Johnson, R.M. (2015). Honey Bee Toxicology. Annual Review of Entomology, 60, 418-434. DOl: 10.1146/annurev-ento-011613-162005

Kamler, F." Titěra, D., Piškulová, J., Hajšlová, J." Maštovká, K. (2003). Intoxication of honeybees on chemical treated winter rape: problem of its verification. Bulletin of Insectology, 56 (1), 125-127.

Kasiotis, K.M., Anagnostopoulos, C., Anastasiadou, P., Machera, K. (2014). Pesticide residues in honeybees, honey and bee pollen by LC-MS/MS screening: Reported death incidents in honeybees. Science of the Total Environment, 485, 633-642. DOl: 10.1016/j.scitotenv.2014.03.042

Kiljanek, T., Niewiadowska, A., Semeniuk, S., Gaweł, M., Borzęcka, M., Posyniak, A. (2016). Multi-residue method for the determination of pesticides and pesticide metabolites in honeybees by liquid and gas chromatography coupled with tandem mass spectrometry-Honeybee poisoning incidents. Journal of Chromatography A, 1435, 100-114. DOl: 10.1016/j.chroma.2016.01.045

Klein, A.M., Vaissiére, B.E., Cane, J.H., SteffanDewenter, l., Cunnigham, S.A., Kremen, C., Tscharntke, T. (2007). Importance of pollinators in changing landscapes for world crops. Proceedings of the Royal Society B-Biological Sciences, 274(1608), 303-313. DOl: 10.1098/rspb.2006.3721

Krohn, P.W., Becker, R.C., \& Hungenberg, H. (2008). United States Patent Application 20080261811. Synergistic mixtures exhibiting insecticidal and fungicidal action. Retrieved April 12, 2016, from http:// www.freepatentsonline.com/y2008/0261811. html

Laurino, D., Porporato, M., Patetta, A., Manino, A. (2011). Toxicity of neonicotinoid insecticides to 
honey bees: laboratory tests. Bulletin of Insectology, 64(1), 107-113.

Lu, C., Warchol, K.M., \& Callahan, R.A. (2014). Sublethal exposure to neonicotinoids impaired honey bees winterization before proceeding to colony collapse disorder. Bulletin of Insectology, 671), 125130.

Łozowicka, B. (2013). The development, validation and application of a GC-dual detector (NPD-ECD) multi-pesticide residue method for monitoring bee poisoning incidents. Ecotoxicology and Environmental Safety, 97, 210-222. D0l: 10.1016/j.ecoenv.2013.07.010

Maini, S., Medrzycki, P., \& Porrini, C. (2010). The puzzle of honey bee losses: a brief review. Bulletin of Insectology, 63(1), 153-160.

Medrzycki, P., Montanari, R., Bortolotti, L., Sabatini, A.G., Maini, S., Porrini, C. (2003). Effects of Imidacloprid administered in sub-lethal doses on honey bees' behaviour. Laboratory tests. Bulletin of Insectology, 56(1), 59-62.

Medrzycki, P., Giffard, H., Aupinel, P., Belzunces, L.P., Chauzat, M.P., Claßen, C., ... Vidau, C. (2013). Standard methods for toxicology research in Apis mellifera. In V Dietemann; I D Ellis; P Neumann (Eds) The COLOSS BEEBOOK, Volume l: standard methods for Apis mellifera research. Journal of Apicultural Research, 52(4), http://dx.doi.org/10.3896/IBRA.1.52.4.14

Mineau, P., Harding, K.M., Whiteside, M., Fletcher, M.R., Garthwaite, D., Knopper, L.D. (2008). Using reports of bee mortality in the field to calibrate laboratory-derived pesticide risk indices. Environmental Entomology, 372), 546-554. DOl: 10.1603/0046-225X(200 8)37[546:UROBMI]2.0.CO;2

Mullin, C.A. (2015). Effects of 'inactive' ingredients on bees. Current Opinion in Insect Science, 10, 194200. DOl: 10.1016/cois.2015.05.006

Mullin, C.A., Chen, J., Fine, J.D., Frazier, M.T., Frazier, J.L. (2015). The formulation makes the honey bee poison. Pesticide Biochemistry and Physiology, 120(SI),
27-35. DOl: 10.1016/j.pestbp.2014.12.026

Narahashi, T., Zhao, X., Ikeda, T., Salgado, V.L., Yeh, J.Z. (2010). Glutamate-activated chloride channels: Unique fipronil targets present in insects but not in mammals. Pesticide Biochemistry and Physiology, 972), 149-152. DOI: 10.1016/j.pestbp.2009.07.008

Nikolakis, A., Chapple, A., Freissleben, R., Neumann, P., Schad, T., Schmuck, R., ... Maus, C. (2009). An effective risk management approach to prevent bee damage due to the emission of abraded seed treatment particles during sowing of seeds treated with bee toxic insecticides. Julius-Kühn Archiv, 423, 132-148.

Pistorius, J., Bischoff, G., Heimbach, U., Stähler, M. (2009). Bee poisoning incidents in Germany in spring 2008 caused by abrasion of active substance from treated seeds during sowing of maize. Julius-Kühn Archiv, 423, 118-126.

Pistorius, J., Wehner, A., Kriszan, M., Bargen, H., Knäbe, S., Klein, O.,... Heimbach, U. (2015). Application of predefined doses of neonicotinoid containing dusts in field trials and acute effects on honey bees. Bulletin of Insectology, 68(2), 161-172.

PIWET (National Veterinary Research Institute). (2016). Zatrucia pszczół. Instrukcja pobierania i przesyłania próbek do laboratoryjnych badań diagnostycznych przy podejrzeniu ostrego zatrucia pszczół środkami ochrony roślin. Retrieved March 31, 2016, from http://www.piwet.pulawy.pl/

Porrini, C., Sabatini, A.G., Girotti, S., Fini, F., Monaco, L., Celli, G.,... Ghini, S. (2003). The death of honey bees and environmental pollution by pesticides: the honey bees as biological indicators. Bulletin of Insectology, 56(1), 147-152.

Porrini, C., Caprio, E., Tesoriero, D., Di Prisco, G. (2014). Using honey bee as bioindicator of chemicals in Campanian agroecosystems (South Italy). Bulletin of Insectology, 671), 137-146.

Regulation (EC) No 1107/2009 of the European Parliament and of the Council of 21 October 2009 concerning the placing of plant protection products on 


\section{J. APR. SCLI. VOL. 60 ND. 2 2016}

the market and repealing Council Directives 79/117/ EEC and 91/414/EEC. (2009). Official Journal of the European Union, 309, 24.11.2009, 1-50.

Reetz, J.E., Zuhlke, S., Spiteller, M., Wallner, K. (2012). A method for identifying water foraging bees by refractometer analysis: a spotlight on daily and seasonal water collecting activities of Apis mellifera L. Journal fur Verbraucherschutz und Lebensmittelsicherheit-Journal of Consumer Protection and Food Safety, 74), 283-290. DOl: 10.1007/s00003-0120799-3

Rondeau, G., Sánchez-Bayo, F., Tennekes, H.A., Decourtye, A., Ramirez-Romero, R., Desneux, N. (2014). Delayed and time-cumulative toxicity of imidacloprid in bees, ants and termites. Scientific Reports, 4, 5566. DOl: 10.1038/srep05566

Rueppell, O., Hayworth, M.K., \& Ross, N.P. (2010). Altruistic self-removal of health compromised honey bee workers from their hive. Journal of Evolutionary Biology, 23(7), 1538-1546. DOl: 10.1111/j.14209101.2010.02022.x

Sanchez-Bayo, F., \& Goka, K. (2014). Pesticide Residues and Bees - A Risk Assessment. PLoS ONE, 9(4), e94482. D0l:10.1371/journal.pone.0094482

Seitz, N., Traynor, K.S., Steinhauer, N., Rennich, K., Wilson, M.E., Ellis, J.D., ... vanEngelsdorp, D. (2015). A national survey of managed honey bee 20142015 annual colony losses in the USA. Journal of Apicultural Research, 54(4), 292-304. DOl: 10.1080/00218839.2016.1153294

Simon-Delso, N., San Martin, G., Bruneau, E., Minsart, L.A., Mouret, C., Hautier, L. (2014). Honeybee colony disorder in crop areas: The role of pesticides and viruses. PLOS ONE, 9(7), e103073. D0l:10.1371/journal.pone.0103073

Simon-Delso, N., Amaral-Rogers, V., Belzunces, L.P." Bonmatin, J.M., Chagnon, M., Downs, C....Wiemers, M. (2015). Systemic insecticides (neonicotinoids and fipronil): trends, uses, mode of action and metabolites. Environmental Science and Pollution Research International, 22, 5-34. DOl: 10.1007/s11356-014-3470-y
Soderlund, D.M. (2010). Toxicology and mode of action of pyrethroid insecticides. In Hayes' Handbook of Pesticide Toxicology. (pp. 1665-1686). San Diego: Elsevier Academic Press. DOl: 10.1016/B978-0-12374367-1.00077-X

Soderlund, D.M., Clark, J.M., Sheets, L.P., Mullin, L.S., Piccirillo, V.j., Sargent, D., ... Weiner, M.L. (2002). Mechanisms of pyrethroid neurotoxicity: implications for cumulative risk assessment. Toxicology, 177(1), 3-59. DOl: 10.1016/S0300-483X(01)00569-8

Stanley, D.A., Garratt, M.P.D., Wickens, J.B., Wickens, J.B., Potts, S.G., Raine, N.E. (2015). Neonicotinoid pesticide exposure impairs crop pollination services provided by bumblebees. Nature, 528(7583), 548-550. DOl: 10.1038/nature16167

Suchail, S., Guez, D., \& Belzunces, L.P. (2001). Discrepancy between acute and chronic toxicity induced by imidacloprid and its metabolites in Apis mellifera. Environmental Toxicology and Chemistry, 2011), 24822486.DOl: 10.1897/1551-5028(2001)020<2482:DB AACT $>2.0 . C 0 ; 2$

Suchail, S., Guez, D., \& Belzunces, L.P. (2001a). Toxicity of imidacloprid and its metabolites in Apis mellifera. Les Colloques de I'INRA, 98, 121-126.

Tapparo, A., Giorio, C., Marzaro, M., Marton, D., Sold, L., Girolami, V. (2011). Rapid analysis of neonicotinoid insecticides in guttation drops of corn seedlings obtained from coated seeds. Journal of Environmental Monitoring, 13(6), 1564-1568. DOl: 10.1039/ clem10085h

Thompson, H.M., \& Thorbahn, D. (2009). Review of honeybee pesticide poisoning incidents in Europe evaluation of the hazard quotient approach for risk assessment. Julius-Kühn Archiv, 423, 103-108.

Thompson, H.M., Fryday, S.L., Harkin, S., Milner, S. (2014). Potential impacts of synergism in honeybees (Apis mellifera) of exposure to neonicotinoids and sprayed fungicides in crops. Apidologie, 45(5), 545-553. DOl: 10.1007/s13592-014-0273-6 
Tomlin, C.D.S. (2009). The e-Pesticide Manual. UK: British Crop Protection Council.

US EPA (United States Environmental Protection Agency). (2013). Guidance for inspecting alleged cases of pesticide-related bee incidents. Retrieved April 1, 2016, from https://www.epa.gov/compliance/guidance-inspecting-alleged-cases-pesticiderelated-bee-incidents

Van der Sluijs, J.P., Simon-Delso, N., Goulson, D., Maxim, L., Bonmatin, J-M., Belzunces, L. (2013). Neonicotinoids, bee disorders and the sustainability of pollinator services. Current Opinion in Environmental Sustainability, 5(3-4), 293-305. D0l:10.1016/j. cosust.2013.05.007

vanEngelsdorp, D., \& Meixner, M.D. (2010). A historical review of managed honey bee populations in Europe and the United States and the factors that may affect them. Journal of Invertebrate Pathology, 103, S80-S95. DOl: 10.1016/j.jip.2009.06.011

Voeste, D., Haden, E., \& Oloumi-Sadeghi, H.R. (2014). European Patent Application EP2679096. Pesticidal mixtures. Retrieved April 12, 2016, from http://www. freepatentsonline.com/y2008/0261811.html

Walorczyk, S., \& Gnusowski, B. (2009). Development and validation of a multi-residue method for the determination of pesticides in honeybees using acetonitrile-based extraction and gas chromatography-tandem quadrupole mass spectrometry. Journal of Chromatography A, 1216(37), 6522-6531. DOl: 10.1016/j.chroma.2009.07.045

Yoder, J.A., Jajack, A.J., Rosselt, A.E., Smith, T.J., Yerke, M.C., Sammataro, D. (2013). Fungicide contamination reduces beneficial fungi in bee bread based on an area-wide field study in honey bee, Apis mellifera, colonies. Journal of Toxicology and Environmental Health-Part A-Current Issues, 76(10), 587-600. DOl: 10.1080/15287394.2013.798846 